\title{
Conservation of Vriesea flammea L.B.Sm., an endemic Brazilian bromeliad: effects of nutrients and carbon source on plant development
}

\author{
M. H. Sasamoria* (D), D. Endres-Júnior ${ }^{a}$ (D) and A. Droste ${ }^{a}$ \\ ${ }^{a}$ Laboratório de Biotecnologia Vegetal, Programa de Pós-graduação em Qualidade Ambiental, Universidade Feevale, \\ ERS-239, 2755, CEP 93525-075, Novo Hamburgo, RS, Brasil \\ *e-mail: marciosasamori@feevale.br
}

Received: October 11, 2018 - Accepted: February 14, 2019 - Distributed: May 31, 2020

(With 2 figures)

\begin{abstract}
Bromeliaceae is restricted to the Neotropical region and has a high degree of endemism, which contributes to increased biodiversity because of the diverse morphological characteristics of individuals. In order to develop an in vitro conservation technology to obtain plants for reintroduction, seeds of Vriesea flammea L.B.Sm. were collected, sterilized and germinated in culture medium. The plants obtained were cultured for 180 days in MS medium with different concentrations of mineral nutrients ( 25 and 50\% of nitrogenous salts and macronutrients), and different concentrations of sucrose $\left(20,30,40,50\right.$ and $\left.60 \mathrm{~g} \mathrm{~L}^{-1}\right)$, and then acclimatized for 150 days on commercial substrate. When seeds were sterilized directly, only $4 \%$ of them were contaminated, whereas sterilization of capsules resulted in $43.6 \%$ contaminated seeds. Germination rates above $80 \%$ were recorded. Low concentrations of nitrogenous salts and macronutrients produced greater than $76 \%$ survival and promoted greater in vitro plant development than the complete MS medium. The development of the aerial system, root system, fresh mass and photosynthetic pigments were positively related to sucrose concentration in vitro. The highest sucrose concentration also indirectly promoted greater development of the aerial system and fresh mass of acclimatized plants. We established conditions for in vitro cultivation and acclimatization for efficient propagation of $V$. flammea with a view towards conservation of the species or reestablishment of natural populations.
\end{abstract}

Keywords: Atlantic Forest, Bromeliaceae, conservation technology, micropropagation.

\section{Conservação de Vriesea flammea L.B.Sm., uma bromélia Brasileira endêmica: efeitos dos nutrientes e fonte de carbono sobre o desenvolvimento das plantas}

\section{Resumo}

Bromeliaceae é restrita à região neotropical, com alto grau de endemismo, que contribui para o aumento da biodiversidade, devido às características morfológicas dos indivíduos. Objetivando desenvolver uma tecnologia in vitro de conservação para obtenção de plantas com vistas à reintrodução, sementes de Vriesea flammea L.B.Sm. foram coletadas, esterilizadas, germinadas em meio de cultura e as plantas obtidas foram cultivadas por 180 dias em meio MS com diferentes concentrações de nutrientes minerais (25 e 50\% dos sais nitrogenados e dos macronutrientes), bem como em diferentes concentrações de sacarose $\left(20,30,40,50\right.$ e $\left.60 \mathrm{~g} \mathrm{~L}^{-1}\right)$. Após, as plantas foram aclimatizadas por 150 dias em substrato comercial. Quando da esterilização das sementes, apenas 4\% destas contaminaram. Por sua vez, a esterilização de cápsulas resultou em $43,6 \%$ de sementes contaminadas. Taxas de germinação superiores a $80 \%$ foram registradas. Baixas concentrações dos sais nitrogenados e de macronutrientes proporcionaram sobrevivência superior a $76 \%$ e promoveram maior desenvolvimento das plantas in vitro do que o meio MS completo. O desenvolvimento do sistema aéreo, radicular, a massa fresca e pigmentos fotossintéticos apresentaram relação positiva com a concentração de sacarose in vitro. A maior concentração de sacarose também propiciou indiretamente maior desenvolvimento do sistema aéreo e massa fresca das plantas aclimatizadas. Estabelecemos as condições de cultivo in vitro e aclimatização para a eficiente propagação de $V$. flammea com vistas à conservação da espécie ou reestabelecimento das populações naturais.

Palavras-chave: Floresta Atlântica, Bromeliaceae, tecnologia de conservação, micropropagação. 


\section{Introduction}

Bromeliaceae is one of the largest families of flowering plants in the Neotropical region, with about 58 genera and 3,408 described species (Luther, 2014; Stevens, 2013). The majority of bromeliads have tanks formed by the arrangement of their leaves, which collects rainwater, atmospheric nutrients and organic debris (Benzing, 2000; Oliveira and Coelho Netto, 2001). Bromeliads are important for the maintenance of forest systems (Lugo and Scatena, 1992; Oliveira, 2004), and for forming microhabitats that contribute to the coexistence of other organisms (Rocha et al., 1997). The family possesses four centers of diversity corresponding to Central America, the Andes, the Guiana Shield and the Atlantic Forest (Givnish et al., 2011), the latter region is characterized by the presence of epiphytic vascular plants (Kersten, 2010), among which Bromeliaceae is one of the most abundant families with a high degree of endemism (Martinelli et al., 2008; Martinelli and Moraes, 2013)

About $70 \%$ of the human population of Brazil is concentrated in the Atlantic Forest domain (Fundação SOS Mata Atlântica, 2018), which, through the disordered occupation of natural environments, has contributed to extensive degradation of the biome and extinction of several species (Pinto et al., 2006; Fundação SOS Mata Atlântica, 2018). The extractivism of native species of bromeliads, which have high ornamental value, has also led several species to the threat of extinction (Martinelli and Moraes, 2013), many of which are still classified as data deficient for evaluation.

In order to reduce anthropic pressures on natural species, in addition to the use of in situ strategies such as the creation of Conservation Units, ex situ conservation strategies have been implemented, among which the use of in vitro culture and other biotechnological tools have proven to be effective for the propagation and conservation of species (Benson, 1999; Decruse et al., 2003; Aggarwal et al., 2012; Endres Junior et al., 2015; 2018). The propagation of native plants for ornamentation can contribute to the reduction of extractivism (Mercier and Nievola, 2003). In addition, plants can be used for live botanical collections and/or restoration and reintroduction programs in natural habitats (Benson, 1999; Decruse et al., 2003; Aggarwal et al., 2012; Endres Junior et al., 2015, 2018).

Vriesea flammea L.B.Sm. is an epiphytic bromeliad endemic to Brazil (Forzza et al., 2018). It is small in size (from 40 to $50 \mathrm{~cm}$ in height) and possesses brownish leaves and dark purple or reddish spots (Reitz, 1983). The leaves are arranged in a rosette, thereby forming a tank, which is densely covered by brown scales. It is heliophytic, or at least occurs in diffuse light, and is quite frequent on branches with greater penetration of sunlight. In its natural habitat, individuals resemble some species of Tillandsia L. (Reitz, 1983). Vriesea flammea occurs in the Atlantic Forest domain within the states of Rio Grande do Sul and Bahia, as well as the state of Pernambuco (Gomes-da-Silva and Costa, 2011; Forzza et al., 2018), but there is little scientific information on its biology and ecology in the specialized literature (Reitz, 1983; Machado and Semir, 2006; Gomes-da-Silva and Costa, 2011; Forzza et al., 2018). In addition, there have been no reports of ex situ propagation and conservation initiatives for $V$. flammea.

In order to obtain plants of Vriesea flammea for reintroduction, the aims of the present study were to: (a) quantify in vitro germination and determine the effectiveness of seed sterilization methods; (b) evaluate the influence of mineral nutrient and carbohydrate concentrations on the survival and development of plants grown in vitro; and (c) analyze the effect of carbohydrate concentration on plant survival and development in ex vitro acclimatization. It is expected that the development of plants will be influenced by lower concentrations of nutrients and by greater carbohydrate concentration in the medium. Bromeliads possess physiological adaptations that optimize the absorption and use of mineral nutrients in epiphytic conditions (Benzing, 2000), and carbohydrates provide metabolic energy and carbon skeletons for individuals under the mixotrophic conditions typical of in vitro culture (Caldas et al., 1998).

\section{Material and Methods}

\subsection{Sterilization and seed germination}

Mature capsules of Vriese a flammea were collected from different individuals from a natural population in South Brazil (29²4'59.84" S; 4954'50.30”'W), in the municipality of Três Cachoeiras, which is in the northeastern region of the state of Rio Grande do Sul. This population occurs in a fragment of dense humid forest. Voucher specimen was deposited at the Herbarium Anchieta (PACA), in the city of São Leopoldo, Brazil. The capsules were washed in running water with commercial detergent, rinsed in distilled water, taken to a laminar flow chamber, and sterilized for 30 seconds in $70 \%$ ethyl alcohol. Then, they were divided into two groups and sterilized by one of two different methods: (I) external sterilization of the capsules, and (II) sterilization of the seeds. In the first methodology (I), the capsules were submerged in 4\% sodium hypochlorite plus $0.1 \%$ Tween ${ }^{\circledR} 20$ detergent for 15 minutes. Afterwards, the capsules were washed four times in autoclaved distilled water and opened with a scalpel to remove the seeds (Droste et al., 2005). The plumose appendages were removed and the seeds were seeded in petri dishes with $30 \mathrm{~mL}$ of semi-solid MS medium (Murashige and Skoog, 1962) for germination, as described by Bencke and Droste (2008). For sterilization of seeds by methodology II, the capsules were opened, the seeds were removed, and the plumose appendages excised. The process of seed sterilization was performed according to the methodology described by Soares et al. (2012), in which seeds were soaked for 10 minutes in autoclaved distilled water $(30 \mathrm{~mL})$ followed by the addition of $15 \mathrm{~mL}$ of sodium hypochlorite $(2.5 \%)$. The seeds were kept in sterilization for 15 minutes at which time $205 \mathrm{~mL}$ of autoclaved distilled water was added to dilute the sodium hypochlorite, thereby reaching a total 
of $250 \mathrm{~mL}$ of solution. The seeds were removed from the solution, dried on sterile absorbent paper and then seeded in petri dishes with the same culture medium as described in methodology I. After sowing, the cultures were kept at a temperature of $26 \pm 1{ }^{\circ} \mathrm{C}$ under a photoperiod of 12 hours with $60 \mu \mathrm{mol} \mathrm{m} \mathrm{m}^{-2} \mathrm{~s}^{-1}$ of light intensity. Forty plates were used for each methodology, each containing 20 seeds. The efficiency of seed sterilization was evaluated by recording visible contamination. Only plates with uncontaminated seeds were used to evaluate germination (emergence of the radicle and the primary leaf). The number of germinated seeds was recorded 75 days after sowing. The length of the aerial portion (LAP), number of roots (NR) and the longest root length (LRL) each individual were recorded 120 days post-sowing.

\subsection{Macronutrient concentrations}

Plants with a LAP of $1.0 \pm 0.2 \mathrm{~cm}$ obtained 120 days post-sowing were cultivated in flasks (volume $200 \mathrm{~mL}$ ) containing $30 \mathrm{~mL}$ of semi-solid MS medium plus $30 \mathrm{~g} \mathrm{~L}^{-1}$ of sucrose, $4 \mathrm{~g} \mathrm{~L}^{-1}$ of Phytagel ${ }^{\mathrm{TM}}$, and $5 \mathrm{~g} \mathrm{~L}^{-1}$ of activated charcoal, with $\mathrm{pH}$ adjusted to 6.4 before autoclaving. The experimental design consisted of reducing the salts of the MS medium, testing the concentrations of 25 and $50 \%$ of nitrogenous salts (treatments referred to as $25 \mathrm{~N}$ and $50 \mathrm{~N}$, respectively) or 25 and $50 \%$ of the macronutrients (treatments referred to as $25 \mathrm{MS}$ and 50MS, respectively). A treatment with the complete formulation of the salts of the MS medium (referred to as 100MS) was used as a reference. For each treatment, 70 individuals were cultivated and distributed in 14 flasks with five plants each, for a total of 350 bromeliads. A subculture was performed every 60 days, and the plants were cultivated for 180 days under the conditions of temperature, photoperiod and light intensity described for germination. Plant survival and concentration of photosynthetic pigments (chlorophyll $a, b$ and carotenoids) were evaluated for each treatment. In addition, the length of the aerial portion (LAP), number of leaves (NL), number of roots (NR), longest root length (LRL) and fresh mass (FM) were evaluated for each individual. To determine the chlorophyll concentration of plants of each treatment, three replicates of $20 \mathrm{mg}$ of fresh leaf mass were collected from individuals of each treatment, which were immersed in $1 \mathrm{~mL}$ of DMSO for 24 hours in a water bath at $65^{\circ} \mathrm{C}$. For each $1 \mathrm{~mL}$ sample, triplicates of $100 \mu \mathrm{L}$ were taken for reading in a spectrophotometer (Spectramax ${ }^{\circledR}$ M3) using a 96-well plate for cell culture. The spectrophotometer readings for chlorophyll $a, b$ and carotenoides were taken at wavelengths of $665 \mathrm{~nm}$, $649 \mathrm{~nm}$ and $480 \mathrm{~nm}$, respectively. The concentrations of the pigments were calculated according to the equations proposed by Wellburn (1994).

\subsection{Sucrose concentration}

Plants with a LAP of $1.0 \pm 0.2 \mathrm{~cm}$, obtained by means of seed germination according to the methodology described above, were transferred to MS medium with different concentrations of sucrose 120 days after sowing.
The treatments consisted of sucrose concentrations of $20,30,40,50$ and $60 \mathrm{~g} \mathrm{~L}^{-1}$, combined with the concentration of $25 \%$ macronutrients (25MS), based on the results of the test described in item 2.2. The plants were cultured in flasks (volume $200 \mathrm{~mL}$ ) containing $30 \mathrm{~mL}$ of MS medium plus $4 \mathrm{~g} \mathrm{~L}^{-1}$ of Phytagel ${ }^{\mathrm{TM}}$, and $5 \mathrm{~g} \mathrm{~L}^{-1}$ of activated charcoal, with $\mathrm{pH}$ adjusted to 6.4 before autoclaving. For each treatment, 70 individuals were cultivated and distributed in 14 flasks with five plants each for a total of 350 bromeliads. A subculture was performed every 60 days and after 180 days of cultivation plant survival and concentration of photosynthetic pigments (chlorophyll $a, b$ and carotenoids) in each treatment were evaluated. The LAP, NL, NR, LRL and FM of the individuals were also measured.

\subsection{Acclimatization}

The plants from the experiment related to carbohydrate concentration in the culture medium (item 2.3) were submitted to acclimatization. After recording data relative to the morphological parameters, the bromeliads from each sucrose treatment were divided into three groups of 15 individuals each, which were planted in sphagnum with a total of 45 plants per treatment. Transparent plastic trays $(24 \mathrm{~cm} \times 18 \mathrm{~cm}, 10 \mathrm{~cm}$ high) with lids were used as containers, and a layer of crushed stone (rose granite $n^{\circ} 1$ ) was placed at the bottom of each tray to aid drainage. The individuals remained in acclimatization in the growth room under a temperature of $26 \pm 1{ }^{\circ} \mathrm{C}$ and with the retention of $70 \%$ of the natural light by means of a black polypropylene shade fabric. To provide the plants with higher humidity, the trays remained with the transparent lids closed for 30 days, which were gradually opened after this period, exposing the individuals to atmospheric air. Plant irrigation was performed manually, keeping the substrate always moist, and leaf fertilizations $\left(1 \mathrm{~g} \mathrm{~L}^{-1}\right)$ were performed biweekly with Peters ${ }^{\circledR}$ professional commercial fertilizer (NPK - 20-20-20). The bromeliads remained in acclimatization for a period of 150 days, and the survival of individuals from each in vitro treatment (20, 30, 40, 50 and $60 \mathrm{~g} \mathrm{~L}^{-1}$ of sucrose), was recorded, as were the concentration of the photosynthetic pigments (chlorophyll $a, b$ and carotenoids) of the plants of each treatment. The LAP, NL, NR, LRL and FM were also measured for each individual.

\subsection{Statistical analysis}

The contamination and seed germination data were transformed into percentages, which were compared by the Chi-square test and the Mann-Whitney test, respectively. The LAP, NR and LRL data for plants 120 days after sowing were compared by the Mann-Whitney test. The survival data for plants propagated in vitro and acclimatized were transformed into percentages and compared by the Kruskal-Wallis test, followed by the Student-Newman-Keuls test. Data on LAP, NL, NR, LRL, FM and photosynthetic pigments were transformed to natural logarithms $[\ln (\mathrm{x}+1)]$ and square roots $[\operatorname{root}(\mathrm{x}+1)]$. Means for salt and sucrose 
concentrations were subjected to analysis of variance (ANOVA) followed by the Tukey's test. Regression analysis was used to estimate the relationships between biotic parameters and sucrose concentrations. Means for the parameters evaluated between the beginning and after 150 days of acclimatization were compared using Student's t-test for paired samples. The data for acclimatization after 150 days were subjected to analysis of variance (ANOVA) followed by Tukey's test. Chi-square, Mann-Whitney and Kruskal-Wallis tests were conducted using BioEstat version 5.3, while ANOVA and Student's t-test for paired samples were performed using SPSS version 20. The probability was set at $5 \%$ for all tests.

\section{Results}

\subsection{Sterilization and seed germination}

Germination of $V$. flammea seeds was significantly higher for external sterilization of the capsule $(87.4 \pm 12.5 \%)$ than sterilization of seeds $(80.5 \pm 14.8 \%)$. On the other hand, the external sterilization of the capsule had a higher contamination percentage (43.6\%), whereas sterilization of the seeds had only $4 \%$ contamination. There were no differences in LAP, NR or LRL between plants obtained from the two methods of sterilization (see Table 1).

\subsection{Macronutrient concentrations}

Cultivation of $V$. flammea in MS medium with reductions of mineral nutrients resulted in 76 to $93 \%$ plant survival. The reduction of nitrogenous salts to $50 \%(50 \mathrm{~N})$ contributed to greater survival of plants and differed significantly from the survival for the treatments with macronutrient reductions $(50 \mathrm{MS}=76 \% ; 25 \mathrm{MS}=79 \%)$, as well as from that of the complete treatment $(100 \mathrm{MS}=79 \%)$. The treatment $25 \mathrm{~N}$ had $86 \%$ plant survival and did not differ from the other treatments $(H=10.121 ; \mathrm{p}=0.038)$.

The reduction of mineral nutrients of the MS medium also contributed to greater development of the aerial system of the plants. The means for LAP varied between 4.4 and $5.1 \mathrm{~cm}$ in treatments with mineral reductions, with the $25 \mathrm{MS}$ treatment having significantly higher means than the $50 \mathrm{~N}$ culture medium and the complete treatment (100MS), which had the lowest mean. The plants of the $50 \mathrm{MS}$ and $25 \mathrm{~N}$ treatments had intermediate values and did not differ significantly from each other or from the $25 \mathrm{MS}$ treatment (see Table 2). For the NL of the plants, means varied between 10.2 and 13.8 leaves, and for the $25 \mathrm{~N}, 50 \mathrm{~N}$ and 50MS media, the means for NL were significantly lower than in $25 \mathrm{MS}$. Individuals in the $100 \mathrm{MS}$ medium had intermediate means for NL (see Table 2).

The root system of plants was also favored by the reduction of nutrients in the culture medium. The longest root length (LRL) varied from 2.2 to $2.4 \mathrm{~cm}$ among the tested media, which presented significantly higher LRL than plants in $100 \mathrm{MS}$ (see Table 2). The highest mean NR was observed in the plants in 25MS, which differed significantly from the means for individuals cultivated in $50 \mathrm{~N}, 50 \mathrm{MS}$ and in the complete medium (100MS) (see Table 2).

As with the morphometric parameters, FM also varied among the media tested. In general, plants with nutrient

Table 1. Percentages (mean \pm standard deviation) of seed contamination and germination and plant morphological parameters.

\begin{tabular}{lccccc}
\hline Sterilization method & Contamination (\%) & Germination (\%) & LAP $(\mathbf{m m})$ & NR & LRL (mm) \\
\hline Capsules & $43.6^{*}$ & $87.4 \pm 12.5^{*}$ & $8.8 \pm 1.3$ & $1.1 \pm 0.2$ & $9.2 \pm 3.8$ \\
Seeds & 4.0 & $80.5 \pm 14.8$ & $9.7 \pm 2.8$ & $1.1 \pm 0.3$ & $8.3 \pm 2.7$ \\
& $\chi 2=20.5$ & $\mathrm{U}=691.5$ & $\mathrm{U}=156.0$ & $\mathrm{U}=190.0$ & $\mathrm{U}=167.5$ \\
$\mathrm{p}$ & $<0.001$ & 0.037 & 0.234 & 0.787 & 0.379 \\
\hline
\end{tabular}

*Indicates significant difference at $5 \%$ probability. Length of the aerial portion (LAP); number of roots (NR); longest root length (LRL).

Table 2. Values (mean \pm standard deviation) for the length of the aerial portion (LAP), number of leaves (NL), longest root length (LRL), number of roots (NR), fresh mass (FM) and photosynthetic pigments (chlorophyll $a, b$ and carotenoids - Chl $a$, $\mathrm{Chl} b$, and Car, respectively) of plants of Vriesea flammea 180 days after cultivation in vitro.

\begin{tabular}{|c|c|c|c|c|c|c|c|}
\hline & \multicolumn{5}{|c|}{ Treatments } & \multirow{2}{*}{$\mathbf{F}$} & \multirow{2}{*}{$\mathbf{p}$} \\
\hline & $25 \mathrm{~N} *$ & $50 \mathrm{~N} *$ & 25MS* & $50 \mathrm{MS} *$ & 100MS* & & \\
\hline $\operatorname{LAP}(\mathrm{cm})$ & $4.6 \pm 1.4 \mathrm{ab}$ & $4.4 \pm 1.5 \mathrm{ab}$ & $5.1 \pm 1.5 \mathrm{a}$ & $4.7 \pm 1.2 \mathrm{a}$ & $4.0 \pm 1.1 b$ & 5.180 & $<0.001$ \\
\hline NL & $10.6 \pm 4.6 b$ & $10.5 \pm 2.3 b$ & $13.8 \pm 8.2 \mathrm{a}$ & $10.2 \pm 2.4 b$ & $11.8 \pm 3.1 \mathrm{ab}$ & 6.498 & $<0.001$ \\
\hline $\operatorname{LRL}(\mathrm{cm})$ & $2.4 \pm 1.1 \mathrm{a}$ & $2.3 \pm 1.0 \mathrm{a}$ & $2.2 \pm 0.9 \mathrm{a}$ & $2.3 \pm 0.9 \mathrm{a}$ & $1.8 \pm 1.7 \mathrm{~b}$ & 4.928 & 0.001 \\
\hline NR & $2.9 \pm 1.5 \mathrm{ab}$ & $2.7 \pm 1.1 b$ & $3.3 \pm 1.5 \mathrm{a}$ & $2.6 \pm 0.8 b c$ & $2.1 \pm 0.7 \mathrm{c}$ & 8.106 & $<0.001$ \\
\hline FM (mg) & $199.5 \pm 134.9 \mathrm{ab}$ & $213.1 \pm 151.0 \mathrm{ab}$ & $250.2 \pm 162.1 \mathrm{a}$ & $208.9 \pm 154.2 \mathrm{ab}$ & $146.0 \pm 67.0 \mathrm{~b}$ & 4.494 & 0.002 \\
\hline Chla $\left(\mathrm{mg} \mathrm{g}^{-1}\right)$ & $213.2 \pm 52.8 \mathrm{ab}$ & $200.6 \pm 9.8 \mathrm{a}$ & $175.0 \pm 38.1 \mathrm{ab}$ & $203.0 \pm 44.1 \mathrm{ab}$ & $162.9 \pm 28.5 b$ & 2.815 & 0.038 \\
\hline $\mathrm{Chl} b\left(\mathrm{mg} \mathrm{g}^{-1}\right)$ & $114.1 \pm 26.7 \mathrm{a}$ & $111.4 \pm 12.7 \mathrm{a}$ & $99.6 \pm 23.9 \mathrm{a}$ & $109.8 \pm 22.0 \mathrm{a}$ & $96.3 \pm 15.8 \mathrm{a}$ & 1.228 & 0.314 \\
\hline $\operatorname{Car}\left(\mathrm{mg} \mathrm{g}^{-1}\right)$ & $34.0 \pm 8.3 \mathrm{a}$ & $32.7 \pm 2.0 \mathrm{a}$ & $29.0 \pm 6.6 \mathrm{a}$ & $34.0 \pm 6.2 \mathrm{a}$ & $28.4 \pm 4.8 \mathrm{a}$ & 1.817 & 0.145 \\
\hline
\end{tabular}

Different letters in a row indicate significant difference between the treatments according to Tukey test a $5 \%$ probability. $* 25 \mathrm{~N}$ and $50 \mathrm{~N}$ - the concentrations of 25 and $50 \%$ of nitrogenous salts; $25 \mathrm{MS}$ and $50 \mathrm{MS}$ - the concentrations of 25 and $50 \%$ of the macronutrients; 100MS - complete formulation of the salts of the MS medium. 
reduction treatments had the highest mean FM, especially those of the 25MS medium, which differed significantly from the plants in the 100MS medium (see Table 2).

Reduction of nutrients in the culture medium did not influence the concentration of photosynthetic pigments of $V$. flammea cultivated in vitro. The leaf chlorophyll $a$ concentration was between 163 and $213 \mathrm{mg} \mathrm{g}^{-1}$, and only plants of the treatments $50 \mathrm{~N}$ and $100 \mathrm{MS}$ differed significantly. The concentrations of chlorophyll $b$ and carotenoids did not differ significantly between treatments, ranging 96 and $114 \mathrm{mg} \mathrm{g}^{-1}$ and 28 and $34 \mathrm{mg} \mathrm{g}^{-1}$, respectively (see Table 2).

\subsection{Sucrose concentration}

The cultivation of $V$. flammea in culture medium with different concentrations of sucrose contributed to high survival of the plants, with survival percentages between
97 and $100 \%$. In general, there was no observed influence of sucrose on survival since all individuals cultivated at the lowest and the highest concentrations of sucrose (20 and $60 \mathrm{~g} \mathrm{~L}^{-1}$, respectively) survived. In addition, plant survival did not show a significant difference between treatments $(\mathrm{H}=3.334 ; \mathrm{p}=0.504)$.

The development of the aerial system of the plants was influenced by increased sucrose concentration in the culture medium, which led to increases in the morphometric parameters evaluated. The linear regression coefficients showed that 39 and $27 \%$ of the variation in LAP and NL, respectively, were related to the carbohydrate concentration of the medium (see Figure 1A). The concentrations of 20 and $30 \mathrm{~g} \mathrm{~L}^{-1}$ of sucrose produced, on average, plants with LAP of $3.7 \mathrm{~cm}$, which differed significantly from individuals of treatments with higher concentrations of sucrose $\left(40,50\right.$ and $\left.60 \mathrm{~g} \mathrm{~L}^{-1}\right)$, with averages between

A
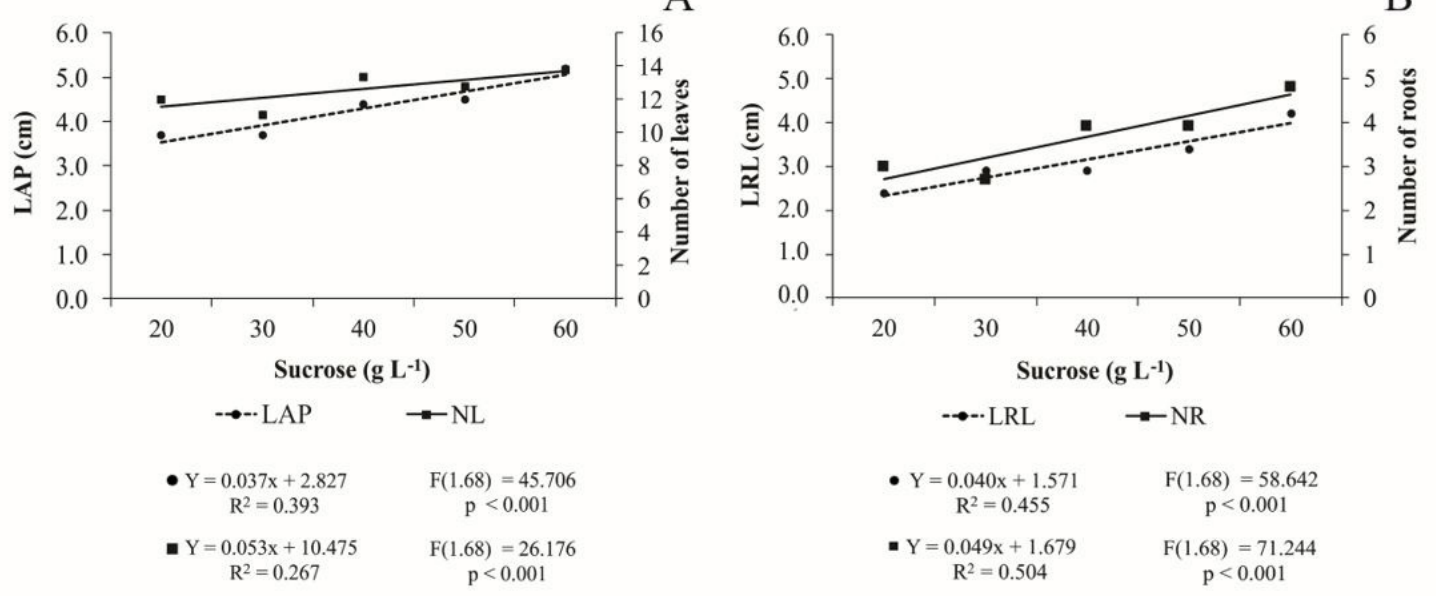

C

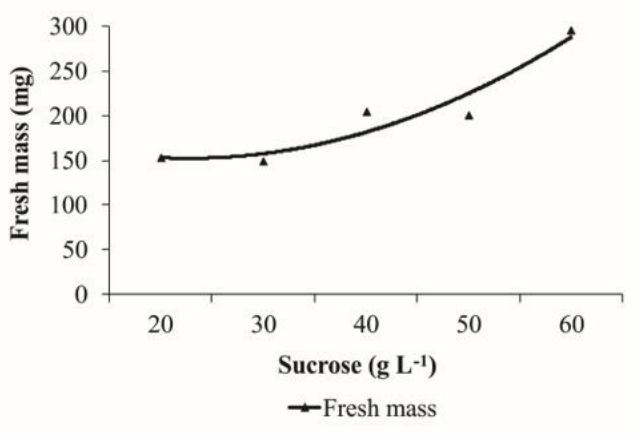

A $\mathrm{Y}=0.00009 \mathrm{x}^{2}-0.004 \mathrm{x}+1.189 \quad \mathrm{~F}(2.67)=24.842$ $\mathrm{R}^{2}=0.409 \quad \mathrm{p}<0.001$

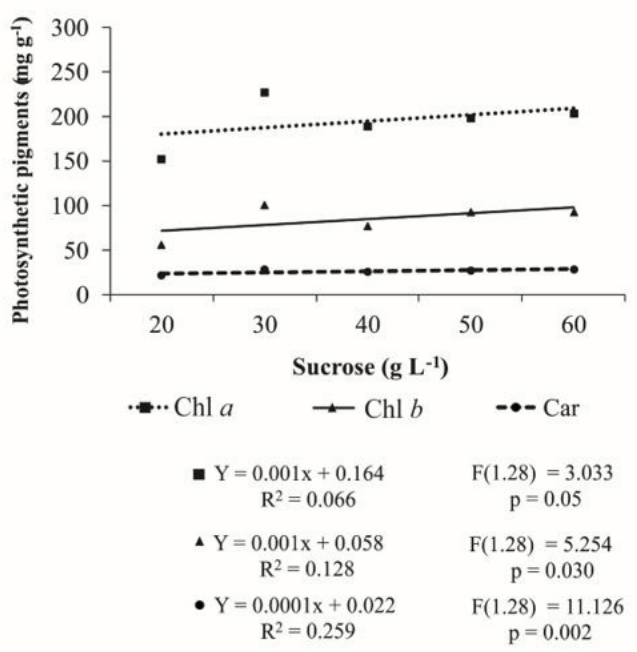

Figure 1. Relationship between biotic parameters and sucrose concentration for plants of Vriesea flammea micropropagated for 180 days in MS medium. $\mathrm{R}^{2}$ - adjusted R square; (A) LAP - length of the aerial portion; NL - number of leaves; (B) LRL - longest root length; NR - number of roots; (C) FM - fresh mass; (D) Chl $a$ - chlorophyll $a$; Chl $b$ - chlorophyll $b$; Car - carotenoids. 
4.4 and $5.2 \mathrm{~cm}(\mathrm{~F}=12.874 ; \mathrm{p}<0.001)$. Likewise, the NL of plants had significantly higher means in the treatments with 40, 50 and $60 \mathrm{~g} \mathrm{~L}^{-1}$ of sucrose (between 12.8 and 13.8 leaves), while the plants in 20 and $30 \mathrm{~g} \mathrm{~L}^{-1}$ had lower means (12.0 and 11.1, respectively; $F=14.576$; $\mathrm{p}<0.001)$.

The root system of plants of $V$. flammea was also influenced by the increase in carbohydrate concentration of the medium. The linear regression coefficient revealed that 45 and $50 \%$ of the variation in LRL and NR, respectively, was explained by the increased sucrose concentration of the culture medium (see Figure 1B). The LRL of the plants was significantly greater in the treatment with $60 \mathrm{~g} \mathrm{~L}^{-1}$ of sucrose $(4.2 \mathrm{~cm} ; \mathrm{F}=16.476 ; \mathrm{p}<0.001)$, whereas plants of the treatments with 30,40 and $50 \mathrm{~g} \mathrm{~L}^{-1}$ of sucrose had intermediate values for this parameter (between 2.9 and $3.4 \mathrm{~cm}$ ). For NR, the highest mean was also observed in the plants of the treatment with $60 \mathrm{~g} \mathrm{~L}^{-1}$ of sucrose (4.8), which differed significantly from the other carbohydrate concentrations $(\mathrm{F}=23.987 ; \mathrm{p}<0.001)$.

Increasing the concentration of sucrose in the culture medium also produced higher FM averages. The regression coefficient indicated that $41 \%$ of the variation in FM was related to the concentration of sucrose in the medium, presenting a polynomial fit for the increase of plant mass (see Figure 1C). As with the other parameters described above, FM of the plants was significantly higher in the treatment with the $60 \mathrm{~g} \mathrm{~L}^{-1}$ concentration of sucrose (296 mg; $F=13.903 ; p<0.001)$. In the other treatments, the values were intermediate and did not differ among them, with mean values of FM between 150 and $201 \mathrm{mg}$.

The photosynthetic pigments of the plant leaf tissues were, in general, related to the concentration of sucrose. Regression coefficients showed that 13 and $26 \%$ of the increase of chlorophyll $b$ and carotenoids, respectively, were related to the increase of sucrose in the culture medium (see Figure 1D). Only chlorophyll $a$ did not have a significant relationship with sucrose. The concentrations of photosynthetic pigments were significantly less in the treatment with $20 \mathrm{~g} \mathrm{~L}^{-1}$ of sucrose (chlorophyll $a$ : $152 \mathrm{mg} \mathrm{g}^{-1}$; $\mathrm{F}=7.294 ; \mathrm{p}<0.001 ;$ chlorophyll $b: 57 \mathrm{mg} \mathrm{g}^{-1} ; \mathrm{F}=5.269$; $\mathrm{p}=0.003$; carotenoids: $22 \mathrm{mg} \mathrm{g}^{-1} ; \mathrm{F}=10.035 ; \mathrm{p}<0.001$ ). The means for the three photosynthetic pigments evaluated under other treatments $\left(30,40,50\right.$ and $\left.60 \mathrm{~g} \mathrm{~L}^{-1}\right)$ did not differ, being between 190 and $228 \mathrm{mg} \mathrm{g}^{-1}$ for chlorophyll $a$, between 78 and $101 \mathrm{mg} \mathrm{g}^{-1}$ for chlorophyll $b$ and between 26 and $29 \mathrm{mg} \mathrm{g}^{-1}$ for carotenoids.

\subsection{Acclimatization}

The acclimatization of plants of $V$. flammea cultivated with different concentrations of sucrose resulted in 68 to $89 \%$ survival after 150 days in the ex vitro environment, with no significant difference among treatments $(F=1.868$; $\mathrm{p}=0.193)$.

The development of acclimatized plants was generally higher with increased sucrose in the culture medium, with significantly higher means for $\operatorname{LAP}(\mathrm{F}=26.248 ; \mathrm{p}<0.001)$, $\mathrm{NL}(\mathrm{F}=13.852 ; \mathrm{p}<0.001), \mathrm{NR}(\mathrm{F}=17.831 ; \mathrm{p}<0.001)$ and FM $(F=40.708 ; p<0.001)$ in the treatment with $60 \mathrm{~g} \mathrm{~L}^{-1}$ of sucrose. For LRL, significantly higher means were observed for the treatments with 50 and $60 \mathrm{~g} \mathrm{~L}^{-1}$ of sucrose $(\mathrm{F}=16.759$; $\mathrm{p}<0.001$; see Figure 2A-E). Conversely, the plants that had been cultivated at the lowest concentrations ( 20 and $30 \mathrm{~g} \mathrm{~L}^{-1}$ ) had significantly lower means for the same parameters. In addition, LAP (between 9.8 and 18.8\%), NL (between 19.5 and 24.6\%) and FM (between 2.0 and $32.1 \%$ ), also increased with the addition of sucrose to the culture medium, even showing significant differences between the initial and final values of acclimatized plants in the treatments between 40 and $60 \mathrm{~g} \mathrm{~L}^{-1}$ of sucrose (see Figure 2A-B and E).

For the root system, a decrease in the length of the longest root was observed in treatments with 20, 40 and $60 \mathrm{~g} \mathrm{~L}^{-1}$ of sucrose $(-4.3,-11.5$ and $-2.4 \%$, respectively). On the other hand, plants of the treatments with 30 and $50 \mathrm{~g} \mathrm{~L}^{-1}$ of sucrose had an increase in root length (3.3 and 8.1\%, respectively). The number of roots increased between 15.2 and $23.5 \%$, resulting in significantly higher means between the initial and final values, with the exception of the treatment with $60 \mathrm{~g} \mathrm{~L}^{-1}$ of sucrose (see Figure 2C-D).

In general, the concentration of photosynthetic pigments increased significantly after 150 days of acclimatization, with the rates of increase being linearly opposite to the increase of sucrose concentration in the medium (Chla: between 26 and 55\%; Chl b: between 36 and 69\%; Car: between 28 and 55\%), resulting in significantly higher means for chlorophyll $a(\mathrm{~F}=6.812 ; \mathrm{p}<0.001)$, chlorophyll $b(\mathrm{~F}=9.473 ; \mathrm{p}<0.001)$ and carotenoids $(\mathrm{F}=15.767$; $\mathrm{p}<0.001)$ in treatments containing low concentrations of sucrose in the culture medium (see Figure 2F-H)

\section{Discussion}

The use of seeds maintains the genetic diversity of propagated individuals, making them suitable for in situ conservation programs (Benson, 1999; Pinto et al., 2010). In addition, in vitro propagation allows plants to be obtained for the reintroduction and conservation of endangered, endemic and key species, such as V. flammea, for the restoration of critically vulnerable biomes (Benson, 1999; Pinto et al., 2010). The micropropagation of native plants for ornamentation can also contribute to the reduction of extractive pressure on natural populations (Mercier and Nievola, 2003), since a large number of individuals can be obtained quickly and efficiently (Mercier and Kerbauy, 1995).

The methodologies used for sterilization of $V$. flammea seeds provided high rates of germination in vitro, comparable to the rates for other species of in vitro germinated bromeliads (Mekers, 1977; Mercier and Kerbauy, 1995; Bencke and Droste, 2008; Sasamori et al., 2016). Despite the success in germination rate, the use of sterile capsules to obtain plants from seeds germinated in vitro was not very feasible since it led to a high degree of contamination of seeds by fungi and bacteria. The use of both methodologies is quite common for obtaining bromeliad or orchid plants by means of seeds 

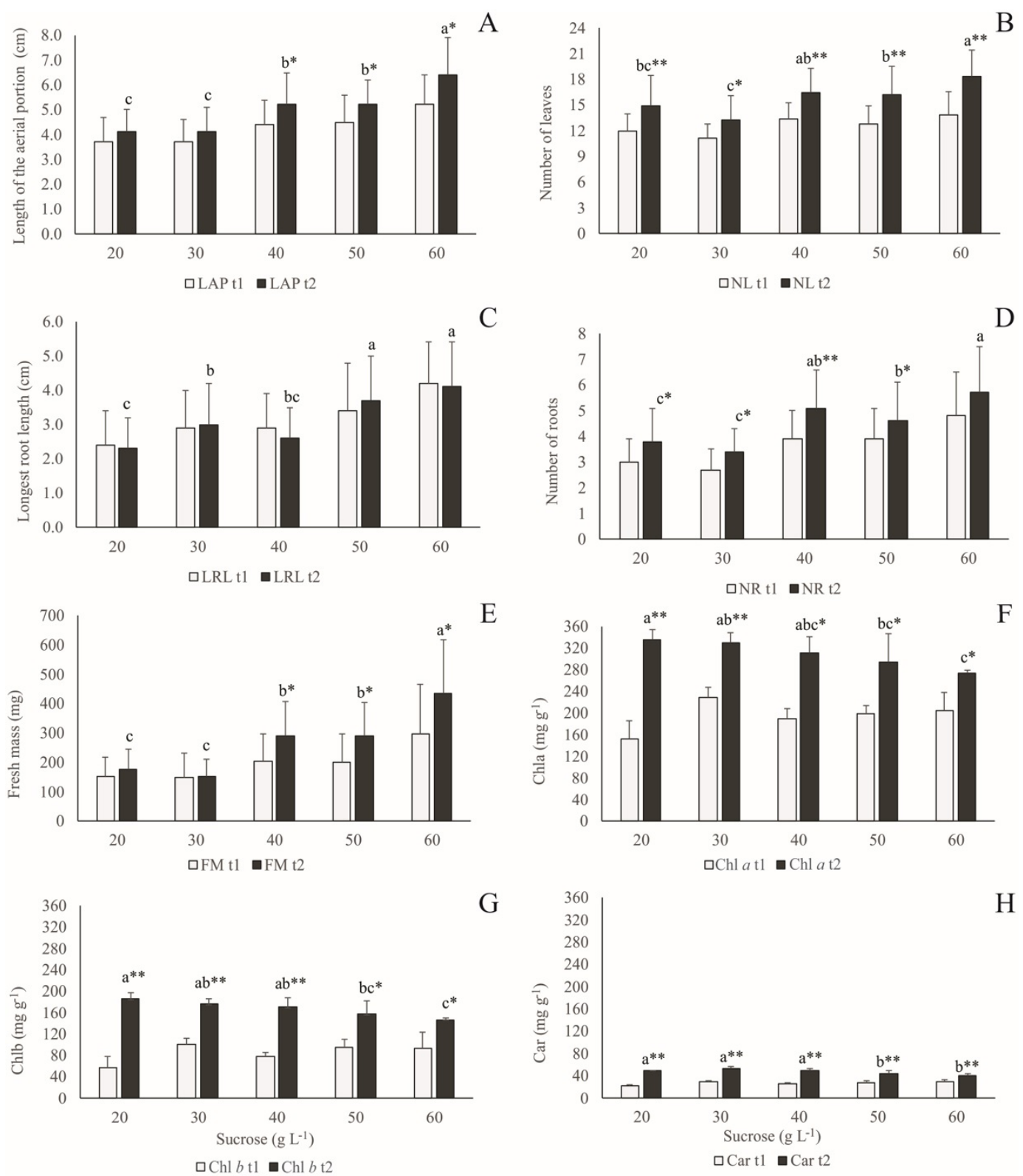

Figure 2. Values (mean \pm standard deviation) of: (A) length of the aerial portion (LAP), (B) number of leaves (NL), (C) longest root length (LRL), (D) number of roots (NR), (E) fresh mass (FM) and (F-H) photosynthetic pigments (chlorophyll $a, b$ and carotenoids - Chl $a, \mathrm{Chl} b$, and Car, respectively) of Vriesea flammea plants initially (gray bars - $\mathrm{t} 1$ ) and after (black bars - t2) 150 days of acclimatization. Different letters indicate significant differences among treatments after acclimatization according to the Tukey test at $5 \%$ probability. Asterisks indicate significant $(* \mathrm{p}<0.05)$ and highly significant $(* * p<0.001)$ differences between the initial and final values of the parameters evaluated for each concentration of sucrose of the in vitro step, according to Student's t-test at $5 \%$ probability.

(Droste et al., 2005; Pedroso et al., 2010; Suzuki et al., 2010; Soares et al., 2012; Endres Júnior et al., 2014; Sasamori et al., 2015; 2016). Vriesea gigantea Gaudich., V. philippocoburgii Wawra and V. incurvata Gaudich. have been micropropagated only by means of sterilization of the capsules, optimizing the process for the cultivation of species with high germination rates (Droste et al., 2005; Sasamori et al., 2016). The presence of small holes in the capsule made by insects or the entrance of microorganisms according to the characteristic of the pericarp of the fruit of $V$. flammea during ripening may be contributing factors for the contamination of seed during micropropagation.

Cultivation of plants in MS medium with different concentrations of macronutrients influenced individual survival and development. The micropropagated $V$. flammea plants had higher mean values for the parameters evaluated 
in the low concentrations of nitrogenous salts and/or macronutrients in the MS medium, corroborating the nutritional requirement of young bromeliads in the natural environment (Adams III and Martin, 1986; Zotz et al., 2004). Tank epiphytic bromeliads generally have two phases in their life cycle. The initial phase is characterized by having similar morphological characteristics to those of atmospheric bromeliads (absence of tank, narrow and linear leaves, high density of trichomes), thus presenting lower nutritional requirements (Adams III and Martin, 1986; Benzing, 2000; Zotz et al., 2004). In the second phase, or the adult phase, the plants possess morphological characteristics in the form of a tank, which allows the accumulation of water, organic matter and animal waste (Benzing, 2000). In this way, bromeliads with a developed tank have greater availability of nutrients, thereby increasing the photosynthetic capacity and nitrogen content of leaf tissues with the passage from the young (atmospheric) phase to the adult (tank) phase (Zotz et al., 2004). In addition, epiphytic plants possess physiological adaptations that optimize the absorption and use of mineral nutrients, which allows them to constantly pass through the stress of nutritional deficiency (Benzing, 2000). Thus, because they do not present a conventional plant nutrition mechanism, species of Bromeliaceae are also good models for studying mineral nutrition (Benzing, 1990).

The results recorded for $V$. flammea corroborate the findings made for other species of bromeliads such as Aechmea blanchetiana (Baker) L.B.Sm., A. bromeliifolia (Rudge) Baker, Alcantarea imperialis (Carrière) Harms, Nidularium minutum Mez and Vriesea incurvata, which also showed higher development of morphometric parameters when grown with low concentrations of nutrients in the culture medium (Fráguas et al., 2002; Kanashiro et al., 2007; Kurita and Tamaki, 2014; Kurita et al., 2014; Sasamori et al., 2016). Because it contains higher amounts of mineral nutrients than other culture media, dilutions of the original formulation of MS medium (Murashige and Skoog, 1962) have been widely used for the propagation of various plant species (Fráguas et al., 2002; Endres Júnior et al., 2014; Kurita et al., 2014; 2015; Sasamori et al., 2015, 2016).

Since epiphytic bromeliads possess physiological adaptations to the lowest nutritional requirement, the nitrogen concentration in the MS medium was also reduced for the propagation of $V$. flammea, which, in general, also showed to be beneficial for the plants. Nitrogen is one of the elements of higher concentration in the MS medium, being made available to plants in the form of nitrate $\left(\mathrm{NO}_{3}^{-}\right)$ and ammonium $\left(\mathrm{NH}_{4}^{+}\right)$(Sakuta et al., 1987; Caldas et al., 1998). Although this element plays an important role in the formation of proteins and chlorophylls (Marenco and Lopes, 2011), elevated concentrations of nitrogen can impair plant growth (Pedroso-de-Moraes et al., 2012), causing acute growth of the aerial system and underdeveloped supporting tissues (Andrade and Tamaki, 2016). On the other hand, the lack of this element can decrease the absorption of other nutrients present in the medium and impair cell metabolism (Nagao et al., 1994).
The reduction of nutrient concentrations was not detrimental to the metabolism of $V$. flammea, since the photosynthetic process related to the availability of mineral nutrients (Taiz and Zeiger, 2013; Marenco and Lopes, 2011), was not affected. The nutritional status or stress of plants, in general, can be diagnosed by photosynthetic pigment content. For the evaluation of nitrogen status in plants, for example, the concentration of chlorophyll has been suggested as a good parameter for diagnosis (Feibo et al., 1998), since chlorophyll content decreases when a plant is deficient in nitrogen (Marschner, 1995). This relationship was evidenced for Ananas comosus (L.) Merr. variety Smooth Cayenne which, when cultivated in the presence of different dilutions of MS medium, showed lower concentration of photosynthetic pigments when plants had nitrogen deficiency (Tamaki et al., 2007).

The addition of sucrose to the culture medium contributed to the development of the aerial system of $V$. flammea plants. Sucrose acts as a carbon source for the cultivated plants, which use it for biosynthesis of structural and functional components of growth (Caldas et al., 1998). In addition, the supply of carbohydrate in the medium can contribute to the expansion of starch reserves in the leaves of plants in vitro, which act as energy storage organs. During the acclimatization stage, starch reserves can provide energy for the growth of new leaves adapted to the ex vitro environment, resulting in greater success in acclimatization (Capellades et al., 1991; Hazarika, 2003; Fuentes et al., 2006).

The calculated coefficients of regression revealed that sucrose had a greater influence on the number and length of the roots than on the aerial system, which is fundamental to the successful acclimatization of micropropagated individuals (Kumar et al., 1999; Besson et al., 2010; Martins et al., 2015). In general, high concentrations of sucrose in the medium positively influence the leaf number and development of plants, although they may also inhibit growth of the aerial part and, at the same time, stimulate the development of the root system (Al-Khateeb, 2008; Martins et al., 2015). For in vitro rooting of plants, in general, carbohydrate concentrations of between 2 and 3\% are used (Grattapaglia and Machado, 1998). However, the cultivation of $V$. flammea and $V$. incurvata (Sasamori et al., 2018) in higher concentrations of sucrose proved to be beneficial for the development of the root system. The carbohydrate source may contribute to the production of growth hormones, such as auxins, which act in the process of rooting through cell expansion and proliferation (Rolland et al., 2002; Wang and Ruan, 2013).

Sucrose stimulation for the growth of the aerial and root systems also produced an increase in the fresh mass of $V$. flammea plants by incorporating carbon (Riek et al., 1997). Carbohydrates added to the culture medium provide metabolic energy and carbon skeletons, as well as organic compounds essential for cell growth (Caldas et al., 1998). Just as for V. flammea, plants of the bromeliad $V$. incurvata and of the orchids Cattleya intermedia Graham and Gomesa varicosa (Lindl.) M.W. Chase \& N.H. Williams also 
showed higher averages for fresh mass and aerial and root systems in treatments with higher sucrose concentration (Rego-Oliveira et al., 2003; Sasamori et al., 2015, 2018).

No inhibition of chlorophyll synthesis was observed for $V$. flammea plants grown at the highest concentrations of sucrose. In in vitro propagation, in general, the inhibition of the photosynthetic process can occur when the plants are grown at high concentrations of carbohydrates (Yamada and Sato, 1978; Capellades et al., 1991; Kozai, 1991; Hdider and Desjardins, 1994), which can stimulate the plants to assume mixed or heterotrophic behavior (Kozai, 1991; Rolland et al., 2002), making them dependent on an exogenous carbohydrate source (Hazarika, 2003; Besson et al., 2010). For $V$. flammea, the maintenance of photosynthetic activity during in vitro culture in the concentrations of sucrose tested can contribute to the rapid establishment of a positive photosynthetic rate, leading to the successful acclimatization of the plants.

The positive influence of the addition of sucrose to the culture medium on the development of $V$. flammea was observed after 150 days of acclimatization in an ex vitro environment. The energy reserves in leaf tissues, due to the higher concentration of sucrose in the medium, and the maintenance of the photosynthetic activity of the individuals propagated in vitro, contributed to the development of the bromeliads, since higher rates of increase and higher means were observed for the parameters length of the aerial portion, number of leaves, number of roots and fresh mass, especially in the medium with $60 \mathrm{~g} \mathrm{~L}^{-1}$ of sucrose. The accumulated sucrose reserves in leaf tissues act as a source of energy for plants during the transition from their mixotrophic to autotrophic metabolism (Capellades et al., 1991; Hazarika, 2003; Fuentes et al., 2006), since the positive photosynthetic rate may require two or more weeks to develop during acclimatization, depending on the species being studied (Hazarika, 2006).

When using lower sucrose concentrations in vitro (between 20 and $40 \mathrm{~g} \mathrm{~L}^{-1}$ of sucrose), higher rates of increase and final values of photosynthetic pigments were observed in acclimatization. The lower availability of sucrose in the culture medium may induce individuals to autotrophic metabolism (Rolland et al., 2002). On the other hand, excess carbohydrates in leaves may result in the repression of photosynthetic genes (Shenn, 1990; Paul and Foyer, 2001). In addition, the accumulation of soluble carbohydrates in the leaf tissues of acclimatized plants may reduce the activity of the rubisco enzyme and the rate of regeneration of carboxylase ribulose 1,5-bisphosphate (Capellades et al., 1991).

The different concentrations of sucrose in the culture medium did not influence the root length of $V$. flammea after 150 days of acclimatization, although sucrose did influence greater root growth of individuals in vitro. In addition, no significant increase or decrease of this parameter was observed after acclimatization. In the acclimatization phase, short roots are desired, since, in addition to facilitating washing and handling during planting, short roots are still in the active phase of growth (Grattapaglia and Machado,
1998). Furthermore, the increase in the number of roots of bromeliads in the in vitro phase, during which sucrose can induce root growth and formation (Grattapaglia and Machado, 1998), was also observed in the acclimatization phase, with root formation producing a completely functional root system for the ex vitro environment.

\section{Conclusion}

High germination rates were obtained from the sterilization of intact capsules and the direct sterilization of seeds without prejudice to the development of the plants. However, the greater contamination of seeds during the sterilization of capsules showed this methodology to be ineffective due to the possible internal contamination of the capsules. Low concentrations of macronutrients and nitrogenous salts promoted greater plant growth in vitro. A positive relationship was found between sucrose concentration and length of the aerial portion, number of leaves, longest root length, number of roots, fresh mass, chlorophyll $b$ and carotenoids in vitro. In addition, an indirect influence of sucrose on the development of the aerial system was observed in the acclimatization phase, when there was a significant increase of the length of the aerial portion, the number of leaves and, consequently, the fresh mass of the plants with the highest concentration of this carbohydrate. The propagation of $V$. flammea was efficient so that plants could be used in reintroduction programs, thus contributing to the reestablishment of natural populations and conservation of the species.

\section{Acknowledgements}

The authors thank the Universidade Feevale for infrastructure and financial support, and Coordenação de Aperfeiçoamento de Pessoal de Nível Superior (CAPES) for a PROSUC scholarship to the first and second authors.

\section{References}

ADAMS III, W.W. and MARTIN, C.E., 1986. Morphological changes accompanying the transition from juvenile (atmospheric) to adult (tank) forms in the Mexican epiphyte Tillandsia deppeana (Bromeliaceae). American Journal of Botany, vol. 73, no. 8, pp. 1207-1214. http://dx.doi.org/10.1002/j.1537-2197.1986.tb08567.x.

AGGARWAL, S., NIRMALA, C., BERI, S., RASTOGI, S. and ADHOLEYA, A., 2012. In vitro symbiotic seed germination and molecular characterization of associeted endophitic fungi in a commercially important and endangered indian orchid Vanda coerulea Griff. Ex Lind. European Journal of Environmental Science, vol. 2, no. 1, pp. 33-42. http://dx.doi.org/10.14712/23361964.2015.36.

AL-KHATEEB, A.A., 2008. Regulation of in vitro bud formation of date palm (Phoenix dactylifera L.) cv. Khanezi by different carbon sources. Bioresource Technology, vol. 99, no. 14, pp. 6550-6555. http://dx.doi.org/10.1016/j.biortech.2007.11.070. PMid:18191564.

ANDRADE, S.V. and TAMAKI, V., 2016. In vitro growth of Nidularium Minutum Mez (Bromeliaceae) in different concentrations of nitrogen, phosphorus, potassium, and calcium. Journal of Plant 
Nutrition, vol. 39, no. 11, pp. 1634-1643. http://dx.doi.org/10.10 80/01904167.2016.1161775.

BENCKE, M. and DROSTE, A., 2008. Otimização da micropropagação de Vriesea gigantea Gaudich. (Bromeliaceae), uma espécie ameaçada de extinção, nativa do Rio Grande do Sul, Brasil. Revista Pesquisas. Botânica, vol. 59, no. 1, pp. 299-306.

BENSON, E.E., 1999. Plant conservation biotechnology. 1st ed. London: Taylor \& Francis, $336 \mathrm{p}$.

BENZING, D.H., 1990. Vascular epiphytes: general biology and related biota. Cambridge: University Press, 376 p. http://dx.doi. org/10.1017/CBO9780511525438.

BENZING, D.H., 2000. Bromeliaceae: profile of an adaptive radiation. Cambridge: University Press, 690 p. http://dx.doi. org/10.1017/CBO9780511565175.

BESSON, J.C.F., OLIVEIRA, L.K., BONETT, L.P. and STEFANELLO, S., 2010. Fontes e concentração de carboidratos no crescimento vegetativo e no enraizamento in vitro de Miltonia flavescens Lindl. Revista Brasileira de Biociências, vol. 8, no. 1, pp. 9-13.

CALDAS, L.S., HARIDASAN, P. and FERREIRA, M.E., 1998. Meios nutritivos. In: A.C. TORRES, L.S. CALDAS and J.A. BUSO, eds. Cultura de tecidos e transformação genética de plantas. 2nd ed. Brasília: Embrapa, pp. 87-132.

CAPELLADES, M., LEMEUR, R. and DEBERGH, P., 1991. Effects of sucrose on starch accumulation and rate of photosynthesis in Rosa cultured in vitro. Plant Cell, Tissue and Organ Culture, vol. 25, no. 1, pp. 21-26. http://dx.doi.org/10.1007/BF00033908.

DECRUSE, S.W., GANGAPRASAD, A., SEENI, S. and MENON, V.S., 2003. Micropropagation and ecorestoration of Vanda spathulata, an exquisite orchid. Plant Cell, Tissue and Organ Culture, vol. 72, no. 2, pp. 199-202. http://dx.doi. org/10.1023/A:1022267009531.

DROSTE, A., SILVA, A.M., MATOS, A.V. and ALMEIDA, J.W., 2005. In vitro culture of Vriesea gigantea and Vriesea philippocoburgii: two vulnerable bromeliads native to southern Brazil. Brazilian Archives of Biology and Technology, vol. 48, no. 5, pp. 717-722. http://dx.doi.org/10.1590/S1516-89132005000600006.

ENDRES JÚNIOR, D., SASAMORI, M.H. and DROSTE, A., 2014. In vitro propagation of Anathallis adenochila (Loefgr.) F. Barros (Orchidaceae), a species endemic to southern and southeastern Brazil. Acta Botanica Brasílica, vol. 28, no. 4, pp. 489-494. http://dx.doi.org/10.1590/0102-33062014abb3158.

ENDRES JÚNIOR, D., SASAMORI, M.H., SCHMITT, J.L. and DROSTE, A., 2018. Survival and development of reintroduced Cattleya intermedia plants related to abiotic factors and herbivory at the edge and in the interior of a forest fragment in South Brazil. Acta Botanica Brasílica, vol. 32, no. 4, pp. 555-566. http://dx.doi. org/10.1590/0102-33062018abb0009.

ENDRES JÚNIOR, D., SASAMORI, M.H., SILVEIRA, T., SCHMITT, J.L. and DROSTE, A., 2015. Reintrodução de Cattleya intermedia Graham (Orchidaceae) em borda e interior de um fragmento de Floresta Estacional Semidecidual no sul do Brasil. Revista Brasileira de Biociências, vol. 13, no. 1, pp. 33-40.

FEIBO, W., LIANGHUAN, W. and FUHUA, X., 1998. Chlorophyll meter to predict nitrogen side dress requirement for short-season cotton (Gossypium hirsutum L.). Field Crops Research, vol. 56, no. 3, pp. 309-314. http://dx.doi.org/10.1016/ S0378-4290(97)00108-1.
FORZZA, R.C., COSTA, A., SIQUEIRA FILHO, J.A., MARTINELLI, G., MONTEIRO, R.F., SANTOS-SILVA, F., SARAIVA, D.P., PAIXÃO-SOUZA, B., LOUZADA, R.B. and VERSIEUX, L., 2018 [viewed 21 June 2018]. Bromeliaceae in lista de espécies da flora do Brasil [online]. Rio de Janeiro: Jardim Botânico do Rio de Janeiro. Available from: http://floradobrasil. jbrj.gov.br/jabot/floradobrasil/FB6461

FRÁGUAS, C.B., PASQUAL, M., DUTRA, L.F. and CHAGAS, E.A., 2002. Desenvolvimento in vitro de plântulas de bromélia: sacarose e concentrações do meio MS. Revista Cientifica Rural, vol. 7, no. 2, pp. 55-63.

FUENTES, G., TALAVERA, C., DESJARDins, Y. and SANTAMARÍA, J.M., 2006. Protocol to achieve photoautotrophic coconut plants cultured in vitro with improved performance ex vitro. In: V.M. LOYOLA-VARGAS and F. VÁZQUEZ-FLOTA, eds. Plant cell culture protocols. Totowa: Humana Press Inc., pp. 131-144.

FUNDAÇÃO SOS MATA ATLÂNTICA, 2018 [viewed 17 june 2018]. Nossas causas [online]. São Paulo: SOS Mata Atlântica. Available from: https://www.sosma.org.br/nossas-causas/mataatlantica

GIVNISH, T.J., BARFUSS, M.H.J., VAN EE, B., RIINA, R., SCHULTE, K., HORRES, R., GONSISKA, P.A., JABAILY, R.S., CRAYN, D.M., SMITH, J.A., WINTER, K., BROWN, G.K., EVANS, T.M., HOLST, B.K., LUTHER, H., TILL, W., ZIZKA, G., BERRY, P.E. and SYTSMA, K.J., 2011. Phylogeny, adaptive radiation, and historical biogeography in Bromeliaceae: Insights from an eight-locus plastid Phylogeny. American Journal of Botany, vol. 98, no. 5, pp. 872-895. http://dx.doi.org/10.3732/ ajb.1000059. PMid:21613186.

GOMES-DA-SILVA, J. and COSTA, A.F., 2011. A taxonomic revision of Vriesea corcovadensis group (Bromeliaceae: Tillandsioideae) with description of two new species. Systematic Botany, vol. 36, no. 2, pp. 291-309. http://dx.doi.org/10.1600/036364411X569499.

GRATtAPAGLiA, D. and MACHADO, M.A., 1998. Micropropagação. In: A.C. TORRES, L.S. CALDAS and J.A. BUSO, eds. Cultura de tecidos e transformação genética de plantas. Brasília: Embrapa, pp. 183-260.

HAZARIKA, B.N., 2003. Acclimatization of tissue-cultured plants. Current Science, vol. 85, no. 12, pp. 1704-1712.

HAZARIKA, B.N., 2006. Morpho-physiological disorders in in vitro culture of plants. Scientia Horticulturae, vol. 108, no. 2, pp. 105-120. http://dx.doi.org/10.1016/j.scienta.2006.01.038.

HDIDER, C. and DESJARDINS, Y., 1994. Effects of sucrose on photosyntesis and phosphoenolpyruvate carboxylase activity of in vitro cultured strawberry plantlets. Plant Cell, Tissue and Organ Culture, vol. 36, no. 1, pp. 27-33. http://dx.doi.org/10.1007/ BF00048312.

KANASHIRO, S., RIBEIRO, R.C.S., GONÇALVES, A.N., DIAS, C.T.S. and JOCYS, T., 2007. Efeitos de diferentes concentrações de nitrogênio no crescimento de Aechmea blanchetiana (Baker) L.B. Sm. cultivada in vitro. Hoehnea, vol. 34, no. 1, pp. 59-66. http://dx.doi.org/10.1590/S2236-89062007000100003.

KERSTEN, R.A., 2010. Epífitas vasculares: histórico, participação taxonômica e aspectos relevantes, com ênfase na Mata Atlântica. Hoehnea, vol. 37, no. 1, pp. 9-38. http://dx.doi.org/10.1590/ S2236-89062010000100001. 
KOZAI, T., 1991. Photoautotrophic micropropagation. In Vitro Cellular \& Developmental Biology. Plant, vol. 27, no. 2, pp. 47-51. http://dx.doi.org/10.1007/BF02632127.

KUMAR, A., SOOD, A., PALNI, L.M.S. and GUPTA, A.K., 1999. In vitro propagation of Gladiolus hybridus Hort.: synergistic effect of heat shock and sucrose on morphogenesis. Plant Cell, Tissue and Organ Culture, vol. 57, no. 2, pp. 105-112. http:// dx.doi.org/10.1023/A:1006373314814.

KURITA, F.M.K. and TAMAKI, V., 2014. In vitro growth of the bromeliad Alcantarea imperialis (Carrière) Harms with different concentrations of nitrogen. Acta Scientiarum. Biological Sciences, vol. 36, no. 3, pp. 279-285. http://dx.doi.org/10.4025/ actascibiolsci.v36i3.22933.

KURITA, F.M.K., MACHADO, B.M., TEIXEIRA, N.B., CESAR, C.G.A., NIEVOLA, C.C. and TAMAKI, V., 2014. Fenologia, cultivo in vitro e aclimatização da bromélia ameaçada de extinção Nidularium minutum Mez. Biotemas, vol. 27, no. 1, pp. 59-69.

LUGO, A.E. and SCATENA, F.N., 1992. Epiphytes and climate change research in the Caribbean: a proposal. Selbyana, vol. 13, pp. 123-130.

LUTHER, H.E., 2014. An alphabetical list of bromeliad binomials. 14th ed. Sarasota: Marie Selby Botanical Gardens \& Bromeliad Society International, $45 \mathrm{p}$.

MACHADO, C. and SEMIR, J., 2006. Fenologia da floração e biologia floral de bromeliáceas ornitófilas de uma área da Mata Atlântica do Sudeste brasileiro. Revista Brasileira de Botanica. Brazilian Journal of Botany, vol. 29, no. 1, pp. 163-174. http:// dx.doi.org/10.1590/S0100-84042006000100014.

MARENCO, R.A. and LOPES, N.F., 2011. Fisiologia vegetal: fotossíntese, respiração, relações hídricas e nutrição mineral. 3nd ed. Viçosa: Universidade Federal de Viçosa, 486 p.

MARSCHNER, H., 1995. Mineral nutrition of higher plants. 2nd ed. London: Academic Press, Harcourt Brace \& Company, 889 p.

MARTINELLI, G. and MORAES, M.A., 2013. Livro vermelho da flora do Brasil. 1st ed. Rio de Janeiro: Instituto de Pesquisas Jardim Botânico do Rio de Janeiro, 1100 p.

MARTINELLI, G., VIEIRA, C.M., GONZALEZ, M., LEITMAN, P., PIRATININGA, A., COSTA, A.F. and FORZZA, R.C., 2008. Bromeliaceae da Mata Atlântica brasileira: lista de espécies, distribuição e conservação. Rodriguésia, vol. 59, no. 1, pp. 209-258. http://dx.doi.org/10.1590/2175-7860200859114.

MARTINS, J.P.R., PASQUAL, M., MARTINS, A.D. and RIBEIRA, S.F., 2015. Effects of salts and sucrose concentrations on in vitro propagation of Billbergia zebrina (Herbert) Lindley (Bromeliaceae). Australian Journal of Crop Science, vol. 9, no. 1, pp. 85-91.

MEKERS, O., 1977. In vitro propagation of some Tillandsioideae (Bromeliaceae). Acta Horticulturae, no. 78, pp. 311-320. http:// dx.doi.org/10.17660/ActaHortic.1977.78.40.

MERCIER, H. and KERBAUY, G.B., 1995. The importance of tissue culture technique for conservation of endangered Brazilian bromeliads from Atlantic rain forest canopy. Selbyana, vol. 16, no. 2, pp. 147-149.

MERCIER, H. and NIEVOLA, C.C., 2003. Obtenção de bromélias in vitro como estratégia de preservação. Vidalia, vol. 1, no. 1, pp. 57-62.

MURASHIGE, T. and SKOOG, F., 1962. A revised medium for rapid growth and bioassays with tobacco tissue cultures.
Physiologia Plantarum, vol. 15, no. 3, pp. 473-497. http://dx.doi. org/10.1111/j.1399-3054.1962.tb08052.x.

NAGAO, E.O., PASQUAL, M. and RAMOS, J.D., 1994. Efeitos da sacarose e do nitrogênio inorgânico sobre a multiplicação in vitro de brotações de porta-enxerto de citros. Bragantia, vol. 53, no. 1, pp. 25-31. http://dx.doi.org/10.1590/S0006-87051994000100003.

OLIVEIRA, R.R. and COELHO NETTO, A.L., 2001. Captura de nutrientes atmosféricos pela vegetação na Ilha Grande, RJ. Revista Pesquisa. Botânica, vol. 51, no. 1, pp. 31-49.

OLIVEIRA, R.R., 2004. A importância das bromélias epífitas na ciclagem de nutrientes da Floresta Atlântica. Acta Botanica Brasílica, vol. 18, no. 4, pp. 793-799. http://dx.doi.org/10.1590/ S0102-33062004000400009.

PAUL, M.J. and FOYER, C.H., 2001. Sink regulation of photosynthesis. Journal of Experimental Botany, vol. 52, no. 360, pp. 1383-1400. http://dx.doi.org/10.1093/jexbot/52.360.1383. PMid:11457898.

PEDROSO, A.N.V., LAZARINI, R.A.M., TAMAKI, V. and NIEVOLA, C.C., 2010. In vitro culture at low temperature and ex vitro acclimatization of Vriesea inflata an ornamental bromeliad. Brazilian Journal of Botany, vol. 33, no. 3, pp. 407-414. http:// dx.doi.org/10.1590/S0100-84042010000300004.

PEDROSO-DE-MORAES, C., SOUZA-LEAL, T., PANOSSO, A.R. and SOUZA, M.C., 2012. Efeitos da escarificação química e da concentração de nitrogênio sobre a germinação e o desenvolvimento in vitro de Vanilla planifólia Jack ex Andr. (Orchidaceae: Vanilloideae). Acta Botanica Brasílica, vol. 26, no. 3, pp. 714-719. http://dx.doi.org/10.1590/S0102-33062012000300022.

PINTO, J.R.S., FREITAS, R.M.O. and PRAXEDES, S.C., 2010. Stimulation of in vitro development of Cattleya granulosa by sucrose. General and Applied Plant Physiology, vol. 36, no. 3-4, pp. 183-188.

PINTO, L.P., BEDÊ, L.C. and FONSECA, M., 2006. Mata Atlântica brasileira: os desafios para a conservação da biodiversidade de um hotspot mundial. In: C.F.D. ROCHA, H.G. BERGALLO, M.V. SLUYS and M.A.S. ALVES, eds. Biologia da conservação: essências. São Carlos: RiMa, pp. 91-118.

REGO-OLIVEIRA, L.V., FARIA, R.T., FONSECA, I.C.B. and SACONATO, C., 2003. Influência da fonte e concentração de carboidrato no crescimento vegetativo e enraizamento in vitro de Oncidium varicosum Lindl. (Orchidaceae). Ciências Agrárias, vol. 24 , no. 2 , pp. 265-272.

REITZ, R., 1983. Bromeliáceas e a malária-bromélia endêmica. In: R. REITZ, ed. Flora ilustrada catarinense. Itajaí: Herbário Barbosa Rodrigues, pp. 808.

RIEK, J., PIQUERAS, A. and DEBERGH, P.C., 1997. Sucrose uptake and metabolismo in a double layer system for micropropagation of Rosa multiflora. Plant Cell, Tissue and Organ Culture, vol. 47, no. 3, pp. 269-278. http://dx.doi.org/10.1007/BF02318982.

ROCHA, C.F.D., COGLIATTI-CARVALHO, L., ALMEIDA, D.R. and FREITAS, A.F.N., 1997. Bromélias: ampliadoras da biodiversidade. Bromelia, vol. 4, no. 4, pp. 7-10.

ROLLAND, F., MOORE, B. and SHEEN, J., 2002. Sugar sensing and signaling in plants. The Plant Cell, vol. 14, (suppl.), pp. 185-205. http://dx.doi.org/10.1105/tpc.010455. PMid:12045277.

SAKUTA, M., TAKAGI, T. and KOMAMINE, A., 1987. Effects of nitrogen source on betacyanin accumulation and growth in suspension cultures of Phytolacca americana. 
Physiologia Plantarum, vol. 71, no. 4, pp. 459-463. http://dx.doi. org/10.1111/j.1399-3054.1987.tb02884.x.

SASAMORI, M.H., ENDRES JÚNIOR, D. and DROSTE, A., 2015. Asymbiotic culture of Cattleya intermedia Graham (Orchidaceae): the influence of macronutrient salts and sucrose concentrations on survival and development of plantlets. Acta Botanica Brasílica, vol. 29, no. 3, pp. 292-298. http://dx.doi. org/10.1590/0102-33062014abb0054.

SASAMORI, M.H., ENDRES JÚNIOR, D. and DROSTE, A., 2016. Low macronutrient concentrations benefit in vitro propagation of Vriesea incurvata (Bromeliaceae), an endemic species of the Atlantic Forest, Brazil. Rodriguésia, vol. 67, no. 4, pp. 1071-1081. http://dx.doi.org/10.1590/2175-7860201667417.

SASAMORI, M.H., ENDRES JÚNIOR, D. and DROSTE, A., 2018. In vitro propagation of Vriesea incurvata: conservation of a bromeliad endemic to the Atlantic Forest. Iheringia. Série Botânica, vol. 73, no. 2, pp. 151-158. http://dx.doi.org/10.21826/24468231201873207.

SHENN, J., 1990. Metabolic repression of transcription in higher plants. The Plant Cell, vol. 2, no. 10, pp. 1027-1038. http://dx.doi. org/10.1105/tpc.2.10.1027. PMid:2136626.

SOARES, J.S., ROSA, Y.B.C.J., MACEDO, M.C., SORGATO, J.C., ROSA, D.B.C.J. and ROSA, C.B.C.J., 2012. Cultivo in vitro de Brassavola tuberculata (Orchidaceae) em meio de cultura alternativo suplementado com diferentes concentrações de açúcar e carvão ativado. Magistra, vol. 24, no. 3, pp. 226-233.

STEVENS, P.F., 2013 [viewed 21 June 2018]. Angiosperm Phylogeny [online]. Available from: http://www.mobot.org/ mobot/research/apweb/
SUZUKI, R.M., ALMEIDA, V., PESCADOR, R. and FERREIRA, W.M., 2010. Germinação e crescimento in vitro de Cattleya bicolor Lindley (Orchidaceae). Hoehnea, vol. 37, no. 4, pp. 731-742. http://dx.doi.org/10.1590/S2236-89062010000400004.

TAIZ, L. and ZEIGER, E., 2013. Fisiologia vegetal. 5th ed. Porto Alegre: Artmed, $954 \mathrm{p}$.

TAMAKI, V., MERCIER, H. and NIEVOLA, C.C., 2007. Cultivo in vitro de clones de Ananas comosus (L.) Merril cultivar 'Smooth Cayenne' em diferentes concentrações de macronutrientes. Hoehnea, vol. 34, no. 1, pp. 69-73. http://dx.doi.org/10.1590/ S2236-89062007000100004.

WANG, L. and RUAN, Y.L., 2013. Regulation of cell division and expansion by sugar and auxin signaling. Frontiers in Plant Science Plant Physiology, vol. 4, no. 1, pp. 1-9.

WELLBURN, A.R., 1994. The spectral determination of chlorophylls $a$ and $b$, as well as total carotenoids, using various solvents with spectrophotometers of different resolution. Journal of Plant Physiology, vol. 144, no. 3, pp. 307-313. http://dx.doi. org/10.1016/S0176-1617(11)81192-2.

YAMADA, Y. and SATO, F., 1978. The photoautotrophic culture of chlorophyllous cell. Plant \& Cell Physiology, vol. 19, no. 4, pp. 691-699.

ZOTZ, G., ENSLIN, A., HARTUNG, W. and ZIEGLER, H., 2004. Physiological and anatomical changes during the early ontogeny of the heteroblastic bromeliad, Vriesea sanguinolenta, do not concur with the morphological change from atmospheric to tank form. Plant, Cell \& Environment, vol. 27, no. 11, pp. 1341-1350. http://dx.doi.org/10.1111/j.1365-3040.2004.01223.x. 